\title{
Activation and active labour market policies in OECD countries: stylised facts and evidence on their effectiveness
}

\author{
John P Martin
}

Correspondence:

Seanomartin@gmail.com

UCD Geary Institute for Public Policy, University College Dublin,

Belfield, Dublin 4, Ireland

\begin{abstract}
Activation policies aimed at getting working-age people off benefits and into work have become a buzzword in labour market policies. Yet they are defined and implemented differently across OECD countries, and their success rates vary too. The Great Recession has posed a severe stress test for these policies, with some commentators arguing that they are at best "fair weather" policies. This paper sheds light on these issues mainly via the lens of recent OECD research. It presents the stylised facts on how OECD countries have responded to the Great Recession in terms of ramping up their spending on active labour market policies (ALMPs), a key component in any activation strategy. It then reviews the macroeconomic evidence on the impact of ALMPs on employment and unemployment rates. This is followed by a review of the key lessons from recent OECD country reviews of activation policies. It concludes with a discussion of crucial unanswered questions about activation.
\end{abstract}

JEL codes: J01, J08, J68

Keywords: Activation; Active labour market policies; Great Recession; Unemployment insurance; Benefit conditionality

\section{Introduction}

The Great Recession which hit the world economy in 2007-8 brought to an abrupt end the period of relatively rapid growth and falling unemployment which had characterised much of the noughties. It led to sharp increases in unemployment in many countries and a resurgence in the numbers of long-term unemployed. While unemployment has subsequently fallen back in the United States from its high of over $10 \%$ in 2010 to under 7\% at the end of 2013, and in Japan too, it has continued to rise in the European Union: the average EU28 harmonised unemployment rate rose from under $7 \%$ in early 2008 to $10.7 \%$ at the end of 2013 .

The increases in unemployment have inevitably brought labour market policies back to centre stage and put the spotlight on the potential of so-called "activation strategies" to help the unemployed, especially the long-term unemployed and other at-risk groups, find jobs. At the beginning, the concept of activation was viewed in a very narrow sense: it meant increasing public resources going into a range of active labour market policies (ALMPs) as opposed to spending public resources on so-called "passive labour market policies", namely unemployment insurance (UI), unemployment assistance 
(UA) and related welfare benefits. The underlying idea was to shift the balance on public spending on labour market policies away from passive spending towards spending on ALMPs and in that way help to reduce structural unemployment (see Appendix 1 for a brief resume of the history of the concept of activation).

However, the evidence from OECD countries' experiences in the 1980s and 1990s suggested that this view of activation was too naïve. It neglected the fact that some countries with relatively low spending on ALMPs maintained low unemployment rates while other countries with above-average ALMP spending experienced rising structural unemployment. It also neglected the fact that economic theory highlighted several potentially important interactions between the generosity of UI systems, the size and mix of ALMP spending and the degree to which benefit eligibility is subject to conditions concerning job search and employability ${ }^{1}$. As a result, the concept of activation was broadened to embrace these different elements and take due account of possible interactions between them.

While there is no agreed definition of the concept, the OECD currently defines activation strategies as aiming:

"to bring more people into the effective labour force, to counteract the potentially negative effects of unemployment and related benefits on work incentives by enforcing their conditionality on active job search and participation in measures to improve employability, and to manage employment services and other labour market measures so that they effectively promote and assist the return to work" ${ }^{2}$.

Drawing on analytical studies and member country experiences in the 1990s and early 2000s, the OECD and the European Commission encouraged member countries to implement effective activation strategies for the unemployed, arguing that the evidence showed that they would help cut unemployment and boost employment. They also argued the case for extending the remit of activation strategies, suitably modified, to other working-age recipients of a range of inactivity benefits such as disability/longterm sickness, early retirement, and sole-parent or social assistance benefits.

The Great Recession and the subsequent hikes in unemployment in many countries have proved to be a severe stress test for activation strategies, and it is opportune to assess how they are standing up to this test bearing in mind that the current job crisis is far from over in many countries.

This paper aims to shed light on this important question via the lens of recent OECD research, notably a series of on-going country reviews of activation policies in selected countries. It will also chart, using the well-known OECD/Eurostat data base on labour market policies, how member countries have responded to rising unemployment in terms of the resources they are devoting to meet this challenge.

The structure of the paper is as follows. Section 1 presents the stylised facts as to how OECD countries have responded to the job crisis in terms of ramping up their ALMP and activation efforts. This is followed by a review of the macroeconomic evidence on the impact of ALMPs on unemployment and employment rates. The third section summarises some of the key lessons that can be drawn from the OECD activation policy reviews. Section 4 highlights some unanswered questions about activation. The final section presents some bottom lines. 


\section{1. Recent trends in labour market policies}

Activation, as noted above, is a tricky concept to define and measure since it involves the institutions responsible for delivering employment services, the payment of UI and related welfare benefits, the rules for monitoring and controlling the behaviour of benefit recipients as they search for work and how these rules are implemented in practice. Ideally, researchers would like to have an agreed and comparable set of indicators of the intensity of activation available across countries and over time with which to compare countries' strategies.

However, no such set of activation indicators exists and researchers must fall back on a second-best option. This involves using the well-known data base compiled by OECD and Eurostat. The standard classification of labour market policies followed by the OECD/Eurostat data base distinguishes between so-called "active" measures (e.g., jobsearch assistance, training, public sector job creation and subsidised employment in the private sector) and "passive" measures (unemployment insurance and related welfare benefits paid to the unemployed). These active and passive measures lie at the heart of any activation strategy, so indicators of their intensity and how it has varied with the onset of the Great Recession can throw light on how activation is being implemented in different countries and over time. Both organisations have been collecting data on their member countries spending on these measures and the numbers of the unemployed participating in these measures for many years. Appendix 2 provides details on the key concepts underlying the data base and some important data comparability issues.

Table 1 presents four alternative indicators of the intensity of ALMPs drawing on the OECD/Eurostat data base: (i) the public spending effort on ALMPs as a per cent of GDP; (ii) the ratio of ALMP spending to spending on UI/UA benefits; (iii) ALMP spending per unemployed; and (iv) the ALMP participation rate measured as the stock of participants on ALMPs as a per cent of the labour force. The indicators are presented for the years 2007 and 2012 in order to highlight the impact of the Great Recession on ALMP intensity.

Several interesting patterns can be discerned from the indicators. First, there are large cross-country differences in the intensity of the public spending effort on ALMPs. Typically, the Nordic countries tend to have relatively high ALMP intensity in terms of the indicators (i) to (iii), while most Anglo-Saxon countries (Australia, Canada, New Zealand, United Kingdom, United States), Japan, Korea and Israel have below-average intensity. Second, while the public spending effort on ALMPs increased in many countries after the Great Recession, it generally failed to match the increase in spending on passive benefits. This can be seen clearly in terms of the trends in indicators (ii) and (iii). In the past, active spending tended to be essentially unresponsive to the business cycle. But, as OECD (2012a) showed, this time is different: public spending on ALMPs has been much more responsive to the increase in unemployment since 2007 than would have been expected on the basis of past business-cycle patterns. However, the increase in spending on ALMPs has not been large enough in most cases to maintain the level of support per unemployed job seeker at the pre-crisis levels. Finally, in terms of indicator (iv), there are large differences in the ALMP participation rate across countries but no clear overall trend during the post-Great Recession period.

The next step is to assess the impact of these measures of ALMP intensity on labour market outcomes. 
Table 1 Indicators of the intensity of ALMPs, 2007 and 2012

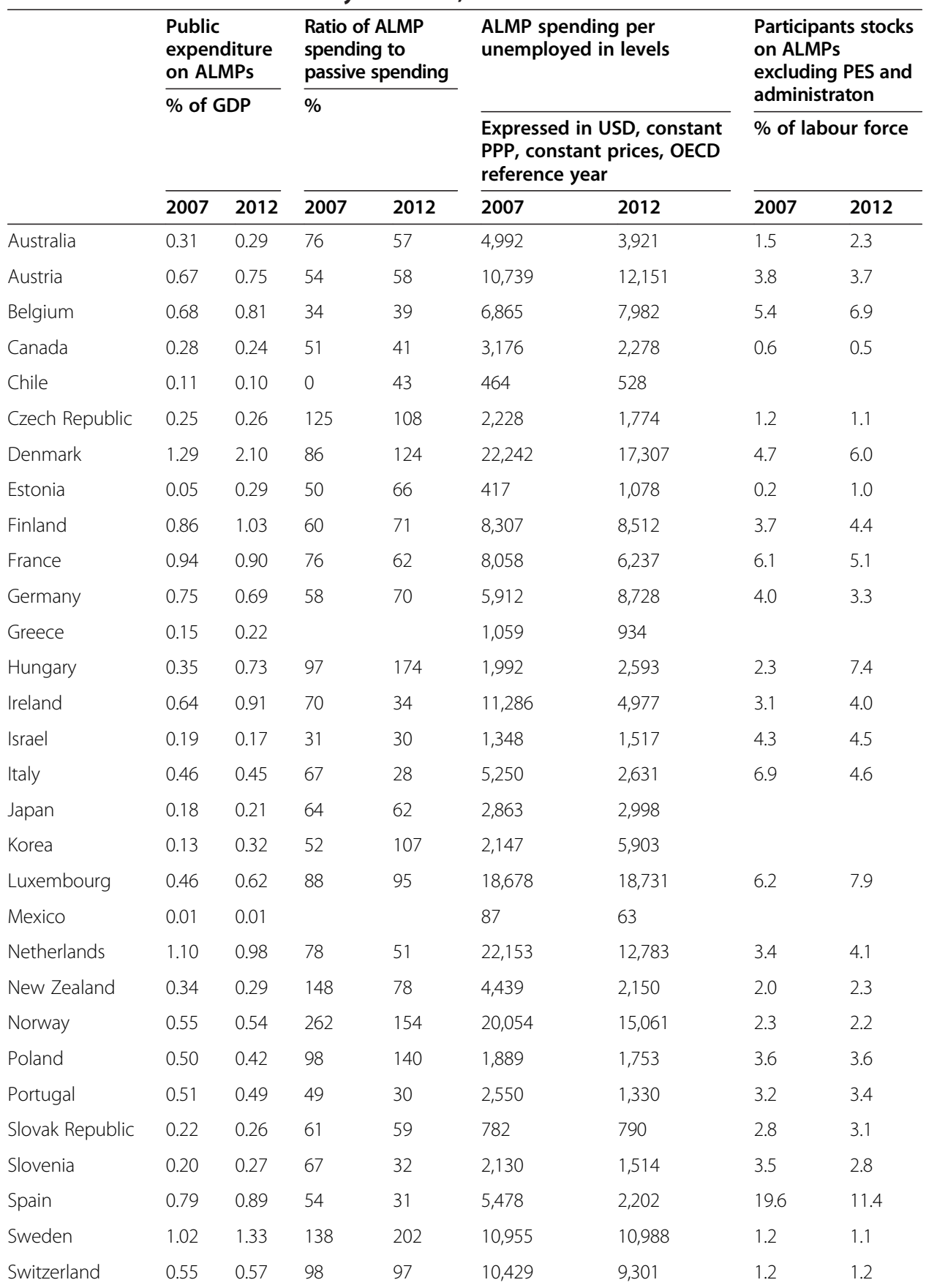


Table 1 Indicators of the intensity of ALMPs, 2007 and 2012 (Continued)

\begin{tabular}{lllllllll}
\hline United Kingdom & 0.31 & 0.41 & 194 & 137 & 4,161 & 3,461 & \\
United States & 0.12 & 0.12 & 40 & 30 & 2,027 & 1,459 & $\mathbf{3 . 6}$ & $\mathbf{3 . 6}$ \\
OECD & $\mathbf{0 . 5 0}$ & $\mathbf{0 . 5 7}$ & $\mathbf{7 2}$ & $\mathbf{6 7}$ & $\mathbf{3 , 9 7 1}$ & $\mathbf{3 , 6 0 5}$ & $\mathbf{3 . 6}$ \\
\hline
\end{tabular}

Note: The data shown should not be treated as strictly comparable across countries or through time, since data at the level of individual countries in some cases deviate from standard definitions and methods, and certain programmes or programme categories are not always included in the data for participants stocks. See www.oecd.org/els/employment-outlook-statisticalannex.htm, which provides a general introductory note about scope and comparability, tables for expenditure and participants in the main programme categories and subcategories, country-specific notes, and access to the online database. Source: For European Union countries and Norway, European Commission (2014), Labour Market Policy (http://epp. eurostat.eu.europa.eu/portal/page/portal/labour_market/labour_market_policy) and detailed underlying data supplied to OECD by the European Commission with certain Secretariat adjustments. For other countries: OECD Database on Labour Market Programmes, http://dx/doi.org/10.1787/data-00312-en.

a. Data for Australia, Ireland, Israel, Luxembourg, Poland and Spain refer to 2011; data for Greece and the United Kingdom refer to 2010; and data for Chile refer to 2008.

\section{2. Macroeconomic evidence on the impact of ALMPs on unemployment}

The impact of ALMPs on labour market outcomes has been assessed through both micro and macro studies. The former consists of a very large body of evidence composed of evaluations of individual ALMPs. Such studies use a range of methods from relatively straightforward comparisons between control groups and programme participants to experimental studies using random assignment of participants. The outcome variables in such studies are typically the exit rate for participants from benefits to a job and/or post-programme earnings. The country coverage of such evaluations has widened considerably in recent years.

In line with the growth in the micro-evaluation literature, there are many good surveys of the findings from this literature, e.g., Heckman et al. (1999); Martin and Grubb (2001); and Card et al. (2010). The picture that emerges from these surveys is one of mixed effectiveness of ALMPs. While there is much variation across studies and across countries, a broad concensus about effectiveness would be as follows: job-search programmes and monitoring of the behaviour of jobseekers tend to be cost-effective; some training programmes, especially those tied to local labour market needs, are also effective once a time window of several years is chosen; targeted hiring subsidies can also work, though these are often subject to significant deadweight and displacement effects; public sector job creation schemes invariably do not work.

While the microeconomic evaluation literature is extremely valuable in quantifying what works and what does not among individual ALMPs, it cannot be used to quantify the macroeconomic effects of ALMP intensity. There are scale effects associated with the size of public spending on ALMPs, and the composition of public spending on the different ALMPs also tends to vary over the cycle. These aggregate effects are not captured in the micro literature.

For this reason, I will focus here on a brief overview of the macroeconomic literature on the impact of ALMPs on the aggregate labour market. This approach typically relies upon cross-country econometric analysis based essentially on large panel data sets. The hypothesis being tested in this literature is that ALMP intensity, if well designed and targeted, can reduce the structural unemployment rate. This is not a new hypothesis: it can be traced back to a seminal 1977 paper by Martin Baily and James Tobin, which argued the case for investing in ALMPs in terms of targeting them to jobseekers with less wage-bargaining power, thereby serving to lower the NAIRU ${ }^{3}$. 
Table 2 gives an overview of selected cross-country econometric studies which have addressed this hypothesis and the principal conclusions that can be drawn from them concerning the macroeconomic effectiveness of ALMP intensity. In interpreting the results, it is important to bear in mind that the econometric estimates of the impact of ALMP intensity on unemployment and employment rates are plagued by endogeneity: this problem arises because ALMP spending is not exogenous but instead responds to changing labour market conditions. Many of the studies in Table 2 are aware of this problem and have tried to control for endogeneity using various instrumental variable methods. But this potential bias still remains an issue in interpreting the findings of the macroeconometric literature on ALMPs.

Putting the endogeneity concern to one side, the majority of the studies reviewed in Table 2 suggest that ALMP spending does reduce unemployment and long-term unemployment. The one major exception to this finding is the study by Baker et al. (2005), which found an insignificant impact. With reference to the concensus findings

Table 2 Macro-econometric evidence of the impact of ALMPs on unemployment and employment

\begin{tabular}{|c|c|c|}
\hline Study & Outcome & Comments \\
\hline Murtin and Robin (2013) & $* *$ & Same result obtained with a structural model. \\
\hline $\begin{array}{l}\text { De Serres and Murtin } \\
\text { (2013) }\end{array}$ & $* *$ & $\begin{array}{l}\text { ALMP spending, particularly on placement and employment services, } \\
\text { reduces unemployment and its persistence over time. }\end{array}$ \\
\hline Estevâo (2003) & $* *$ & $\begin{array}{l}\text { ALMP spending increased business-sector employment rates in } 15 \\
\text { OECD countries in the 1990s. ALMPs also fostered real wage } \\
\text { moderation. }\end{array}$ \\
\hline $\begin{array}{l}\text { Bassanini and Duval } \\
(2006,2009)\end{array}$ & $* *$ & $\begin{array}{l}\text { Spending on labour-market training lowers unemployment; high ALMP } \\
\text { spending also reduces the increase in unemployment associated with } \\
\text { generous unemployment benefits and negative shocks. }\end{array}$ \\
\hline $\begin{array}{l}\text { Baker, Glyn, Howell and } \\
\text { Schmitt (2005) }\end{array}$ & No & ALMP effect insignificant. \\
\hline Belot and Van Ours (2004) & $* *$ & $\begin{array}{l}\text { ALMP spending on labour-market training lowers unemployment } \\
\text { substantially, smaller negative impact for PES spending and none for } \\
\text { subsidised jobs; higher spending on training reduces the negative } \\
\text { impact of unemployment benefits in raising unemployment. }\end{array}$ \\
\hline $\begin{array}{l}\text { Fitoussi, Jestaz, Phelps } \\
\text { and Zoega (2000) }\end{array}$ & ** & $\begin{array}{l}\text { ALMP spending reduces unemployment; the coefficient is insignificant } \\
\text { when Sweden is excluded from the sample. }\end{array}$ \\
\hline $\begin{array}{l}\text { Bertola, Blau and Khan } \\
(2002 a, 2002 b)\end{array}$ & n.a. & $\begin{array}{l}\text { ALMPs only entered in interaction terms which generally are not } \\
\text { significant. }\end{array}$ \\
\hline $\begin{array}{l}\text { Blanchard and Wolfers } \\
\text { (2000) }\end{array}$ & n.a. & $\begin{array}{l}\text { ALMP only entered in interaction terms; higher ALMP spending reduces } \\
\text { the responsiveness of unemployment to negative shocks. }\end{array}$ \\
\hline $\begin{array}{l}\text { Elmeskov, Martin and } \\
\text { Scarpetta (1998) }\end{array}$ & ** & $\begin{array}{l}\text { Replicates the finding in Scarpetta (1996) that ALMP spending has a } \\
\text { small negative impact on unemployment, but a much bigger impact if } \\
\text { Sweden is excluded from the sample. Presents evidence of significant } \\
\text { interactions between ALMP spending and UI benefit replacement rates. }\end{array}$ \\
\hline Nickell (1997, 1998) & ** & For long-term unemployed only. \\
\hline Scarpetta (1996) & $* *$ & $\begin{array}{l}\text { Small impact on reducing unemployment that becomes larger and } \\
\text { more significant with Sweden excluded. }\end{array}$ \\
\hline OECD (2009) & * & $\begin{array}{l}\text { Looks at the impact of ALMPs on unemployment dynamics; shows that } \\
\text { the effectiveness of ALMP spending in raising the exit rate from } \\
\text { unemployment depends on the business cycle; the effectiveness of } \\
\text { jobseeker support and labour demand policies decreases in a } \\
\text { depressed labour market while training becomes more effective. }\end{array}$ \\
\hline
\end{tabular}

No: No significant direct impact on unemployment.

n.a.: Not available.

*: Significant positive/negative impact on unemployment in most but not all cases.

**: Significant negative impact on unemployment in all cases. 
in the micro-evaluation literature on the effectiveness of individual ALMPs noted above, a few of the studies in Table 2 try to disaggregate between the four major types of ALMPs: job-search assistance, training, public sector employment and wage subsidies. It is encouraging that they find results as to the effectiveness of the different ALMPs which match those that come from surveys of the microeconomic evaluation literature ${ }^{4}$.

In sum, the weight of evidence from the macroeconometric cross-country literature is that ALMP intensity, which is a key component in an activation strategy, can help cut unemployment.

\section{3. Key lessons from the OECD activation policy reviews ${ }^{5}$}

This section seeks to complement the previous one by focussing on country case studies that the OECD is conducting on activation policies in member countries since 2008. So far, it has published reviews of seven countries: Ireland ${ }^{6}$, Norway ${ }^{7}$, Finland ${ }^{8}$, Switzerland ${ }^{9}$, $\operatorname{Tapan}^{10}$, Australia ${ }^{11}$ and the United Kingdom ${ }^{12}$. The aim of the reviews is to highlight the factors that result in effective activation from those that do not and to make policy recommendations to countries to improve their activation strategies and/ or to adapt them to changing conditions.

The reviews address a range of questions: How do benefit generosity, decentralisation of the public employment service (PES) and specific interventions affect unemployment spells? How are these interactions interpreted in the context of the countries under review by taking account of the fact that their histories and starting points are different? How can activation policies that are designed to assist unemployment benefit recipients get back to work be adapted to assist working-age recipients of other inactive benefits with very different needs?

In what follows, I summarise my views on the main lessons from the reviews. But it is important to read the published reviews and the overview published in OECD (2013a) to get the full flavour of the analyses and policy recommendations. One important caveat to bear in mind is that the seven countries in question are not a representative sample of OECD countries, and there is a selection bias in that they put themselves forward for review by the OECD Secretariat.

\subsection{Japan: the PES experiences the positive spillover from a "Chasm" in benefit coverage}

Figure 1 shows the trend in the Japanese unemployment rate since 1970. It highlights the very low unemployment rates prior to the two oil price shocks of the 1970s, the persistent upward drift in the unemployment rate that occurred in the 1980 s, 1990 s and the early 2000 s bringing it to a peak of over $5 \%$, and the subsequent drop to below $4 \%$ currently, despite a brief hike when the Great Recession hit. Thus, while structural unemployment has increased in Japan over the past three decades, the rise has been contained to moderate levels which other OECD countries can only envy.

The OECD review argues that this relative success is due, in part, to the specific conditions within which activation operates in Japan. In particular, the review highlights what it terms as a "chasm in benefit coverage" in Japan. The chasm occurs because there are very strict restrictions on eligibility for 


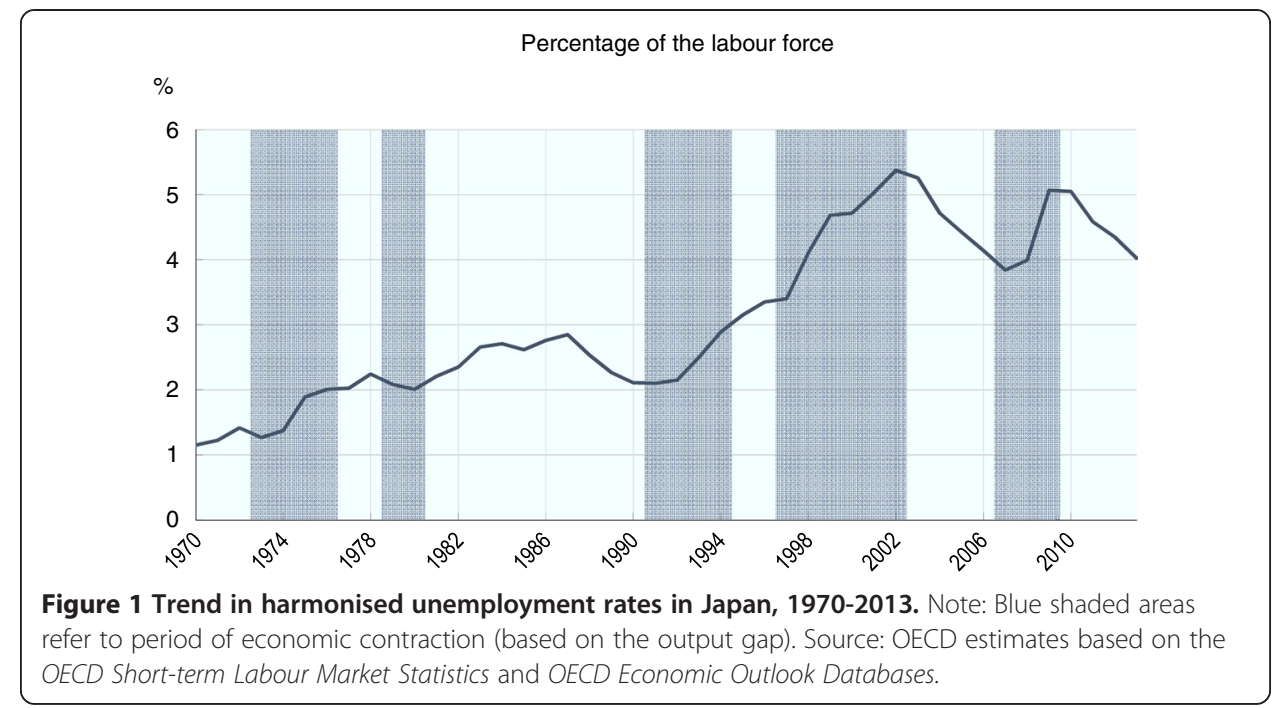

unemployment benefits. Unemployment benefit eligibility being extremely restricted compared with other countries, social assistance is the last-resort income support for those unemployed in Japan who are either ineligible for UI benefits or who have exhausted their entitlements-the duration of UI benefits is relatively short in Japan compared with the vast majority of other OECD countries. Eligibility for social assistance in Japan is also very strict: it is based on stringent asset tests, and Duell et al. (2010a) show that there is very strict application of these asset tests, at the local level.

The upshot of this is that an unemployed person in Japan who has no UI benefit eligibility, or who has exhausted this benefit entitlement, has a very strong incentive to find work. In this specific situation, the Japanese PES does not need to devote a major effort to activation since the unemployed have strong work incentives. As a result, the activation effort in Japan, as measured by the public spending effort on ALMPs, is relatively small. In 2012, Japan spent only $0.2 \%$ of GDP on ALMPs, less than half of the OECD average.

In countries such as Japan where eligibility for UI benefits is strict and benefit levels as proxied by the net (after-tax) benefit replacement rate - are not very generous compared with most other OECD countries, the intensity of activation can be rather mild. In addition, the OECD review gives the Japanese PES a reasonably effective rating. Thus, the combination of a not-too-generous UI/SA benefit system with relatively mild activation has enabled Japan to maintain its unemployment rate within the 4-5\% range.

\subsection{Ireland: high public spending effort on ALMPs but no activation, at least until recently}

Figure 2 shows the roller-coaster ride of the Irish unemployment rate over the past three decades. Following the two oil price shocks, the unemployment rose sharply to a peak of $17 \%$ in the mid-1980s. It remained close to this peak until the mid-1990s. Then the prolonged period of rapid economic growth-the so-called "Celtic Tiger" period- 


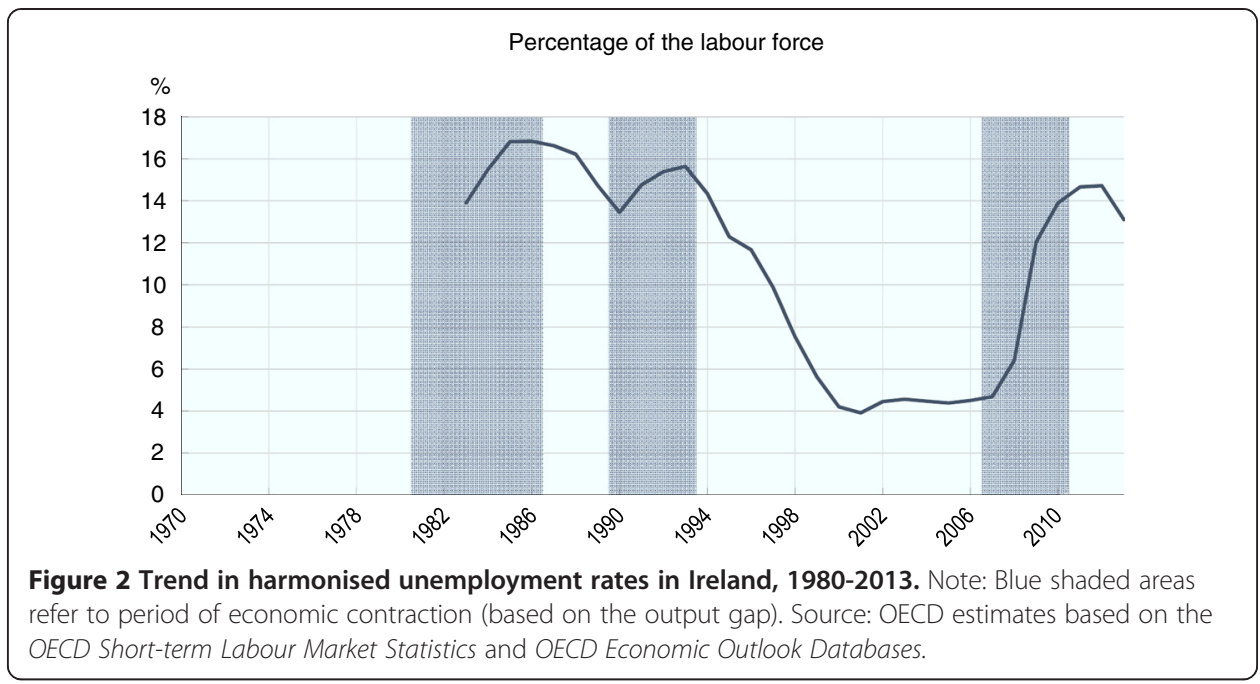

saw the unemployment rate drop steadily to just over $4 \%$ in 2000 , and it remained very stable around this trough until the Great Recession hit. As the Great Recession coincided with the bursting of a big property bubble in Ireland, the Irish economy slumped, and unemployment soared to a peak of over 15\% in 2012 before beginning to fall back as the economy has recovered. The unemployment rate is currently around $11 \%$.

The Irish review-see Grubb et al. (2009)-highlighted the fact that Ireland was like the emperor who had no clothes insofar as activation was concerned! There was much lip service paid by the Irish authorities to activation principles, and the public spending effort on ALMPs was well above average: in 2011, the Irish public spending effort was $0.9 \%$ of GDP compared with an OECD average of just under $0.6 \%$. But there was no implementation of the principles. The Irish legislation said that the unemployed had to engage in active job search as a condition of receiving benefits, their behaviour had to be monitored effectively, etc. None of this was implemented in practice. Part of the explanation for this lack of implementation of the basic principles of activation in Ireland was due to the complacency that came from a period in which the economy experienced full employment for almost a decade. During this period, the Irish PES (Fas) and the benefit agency basically left the unemployed to their own devices.

The situation has changed radically since 2008. The steep hike in unemployment post 2008 coincided with a dramatic loss of public confidence in Fas due to a series of internal scandals which attracted widespread negative publicity. This forced the Irish authorities to shift course radically. They began by amalgamating the benefits agency with the PES to form a new "one-stop-shop" service called Intreo. By the way, the OECD had been urging the Irish authorities for about 15 years to undertake this amalgamation as a way of improving activation, and they had steadfastly ignored its advice until the crisis hit and Fas collapsed-an example of the crisis producing at least one positive outcome!

Reforms were also introduced to the benefit system. During the Celtic Tiger period, Ireland increased the generosity of its benefits system very significantly. Indeed, the increase in net benefit replacement rates over the period from the end of the 1990s to 2007 was one of the largest in the OECD countries, moving Ireland from about average in terms of benefit generosity to one of the top countries. However, driven by both the 
imperative need for fiscal consolidation to rein in the large public sector deficit and the desire to boost work incentives for the unemployed, benefit generosity has been cut back in recent years ${ }^{13}$.

The Irish authorities have taken many steps to ensure that Intreo will operate an effective activation regime from now on. But they face huge obstacles given the very large stocks of unemployed, especially of the long-term unemployed whose share of total unemployment doubled from almost 30\% in 2007 to over 60\% in 2013.

In order to increase the capacity of Intreo to cope with such large numbers of longterm unemployed, the Irish authorities have announced plans to launch an innovative programme called JobPath. Under this new programme, the Irish Department of Social Protection will sub-contract reemployment services with private employment agencies under performance-related contracts-in taking this major step, they have been much influenced by the examples of the UK's Work Programme and Australia's Job Services Australia $^{14}$. But the experiences of both Australia and the UK suggest that it is a very difficult and time-consuming task to design and implement such contracts with private employment service providers in ways that will yield the desired economic and social outcomes, especially for the long-term unemployed. In addition, the few micro studies which have been conducted in Ireland to date have highlighted the ineffectiveness of most of the existing ALMPs and the lack of adequate targeting of them to the needs of the long-term unemployed ${ }^{15}$.

In sum, Ireland is at long last trying to design and implement an effective activation strategy. But it will require a new mentality in the agencies involved in the exercise and a change in social norms, a willingness to enforce job-search requirements effectively and the development of a performance-oriented culture in Intreo that will focus on getting the unemployed off benefits and into work. This is likely to be a long-haul task in Ireland.

\subsection{Finland: a unique PES structure, a unique history and poor outcomes in the past-but looking better now}

Finland, like Ireland, has experienced a roller-coaster ride in its unemployment rate since the end of the 1980s. While there was an increase in unemployment in the 1970s following the two oil price shocks, Finnish unemployment was relatively stable at around $4 \%$ during the 1980s. The situation changed dramatically at the beginning of the 1990s. Finland underwent a serious economic slump following the collapse of the former Soviet Union and the bursting of a local property bubble. This led to a huge spike in the unemployment rate, which peaked at over $16 \%$ in the mid-1990s (see Figure 3). It then dropped back steadily to a low of $6.4 \%$ before it rose again following the Great Recession.

The Finnish economy was particularly hard hit by the Great Recession: it underwent a double dip post 2008, and output at the time of writing is still about $6 \%$ below its 2007 peak. Against this background, the subsequent increase in unemployment was surprisingly moderate, and the Finnish unemployment rate in 2014 Q3 (8.6\%, seasonally adjusted) was still well below the euro area average of $11.5 \%$. In addition, unlike the situation in many other EU countries, there was no increase in the incidence of long-term unemployment in Finland: indeed, the share of long-term unemployment in 


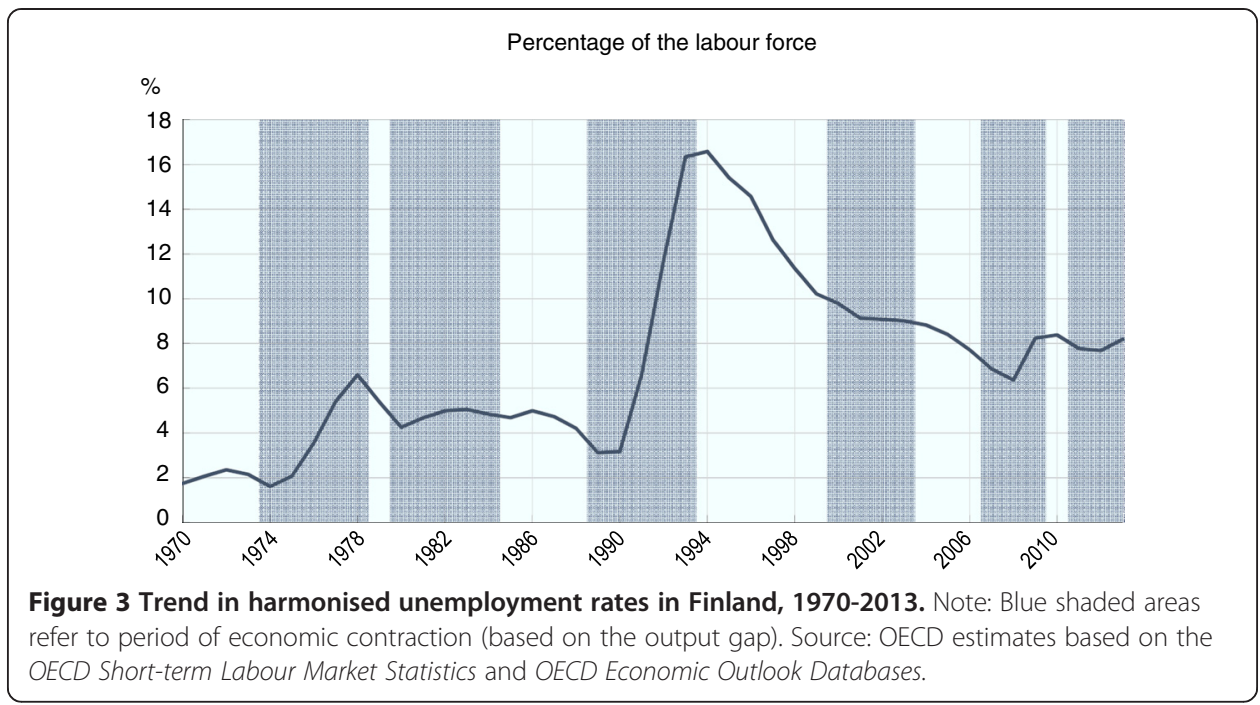

total unemployment was $21.2 \%$ in 2013, below its level in 2007 (23\%). OECD (2014b) attributes this relative success in moderating the rise in overall unemployment and stabilising the share of long-term unemployment in the face of a steep downturn to relatively effective activation policies. However, the latter is a fairly recent phenomenon.

The roller-coaster pattern of the Finnish unemployment rate over the past two decades reflects in part, as Duell et al. (2009a) show, a past history of relatively ineffective activation due to a unique and weak decentralised PES structure interacting with national financing of the benefit system. This system has been transformed significantly over the past decade, resulting in the improved performance cited above.

The Finnish PES has no national-level management. It is effectively managed at the local level by local labour committees which bring together the social partners and the benefit agencies. These committees determine not only benefit eligibility but also the degree to which benefit sanctions for non-respect of job-search obligations and other benefit eligibility criteria are applied at the local level. Municipalities, which are responsible for social assistance benefits, also provide some reemployment services for their unemployed clients. In 2004, separate labour force service centres were established, drawing upon staff from the local PES offices and the municipal services to provide more specialised assistance to the most at-risk job seekers.

There was national financing of the benefit system in the 1980s and 1990s, and this, combined with the de facto local management of the activation system, led to persistently high unemployment following the steep downturn of the early 1990s. A very important reform of the financing of the benefit system, particularly at the local level, took place in 2006 when the municipalities accepted to pay half of the cost of benefits for the long-term unemployed. This forced them to attach much greater importance to effective activation and to try to ensure that the suite of ALMPs at their disposal is a cost-effective one.

Unlike the Irish case, the Finnish authorities were unwilling to lower the relatively generous benefit replacement rates in the UI system to improve work incentives. Instead, they have relied on enforcing stricter conditionality in the benefit system combined with greater emphasis on cost-effective ALMPs to yield better labour market 
outcomes. Finland, it should be noted, has consistently devoted more resources to ALMPs than either the OECD or EU averages: in 2012, its active spending effort was just over $1 \%$ of GDP.

As a result of these reforms, outcomes improved significantly over the past decade, even allowing for the hike in unemployment following the Great Recession. The Finnish case is an interesting illustration of how the interaction between the financing of the benefit system and the local responsibilities for the design and delivery of employment services, if they are tied one to the other, can increase the incentives for local actors to make activation more effective. It is also an interesting case study of a country which has managed to offset the adverse work incentive effects of a relatively generous benefit system by imposing strict benefit conditionality and making use of referrals to a relatively effective set of ALMPs.

\subsection{Australia: active national management a key factor behind the success of the quasi-market for employment services}

As Figure 4 shows, there was a persistent upward trend in the Australian unemployment rate across successive business cycles from 1970 to the mid-1990s. The unemployment rate peaked at around $11 \%$ and then began a prolonged period of decline which brought it to a low of just over $4 \%$ in 2008 before the Great Recession began to bite. While there has been some increase in unemployment since then, the rise has been very moderate and the current unemployment rate of around $6 \%$ is well below the OECD and EU averages.

Since the mid-1990s, the Australian employment rate has increased by almost 10 percentage points to $72 \%$ in 2013 compared with an OECD average of just over $65 \%$. The incidence of long-term unemployment in Australia, even though it has risen slightly since 2008, at 19.3\% in 2013, was far below the OECD average of $35.3 \%$.

OECD (2012b) concludes that the Australian innovation of relying upon a quasimarket in employment services to activate benefit recipients and, in particular, the way in which the market design of the pay-for-performance systems and the incentives provided to reward efficient providers and drive out from the market below-average

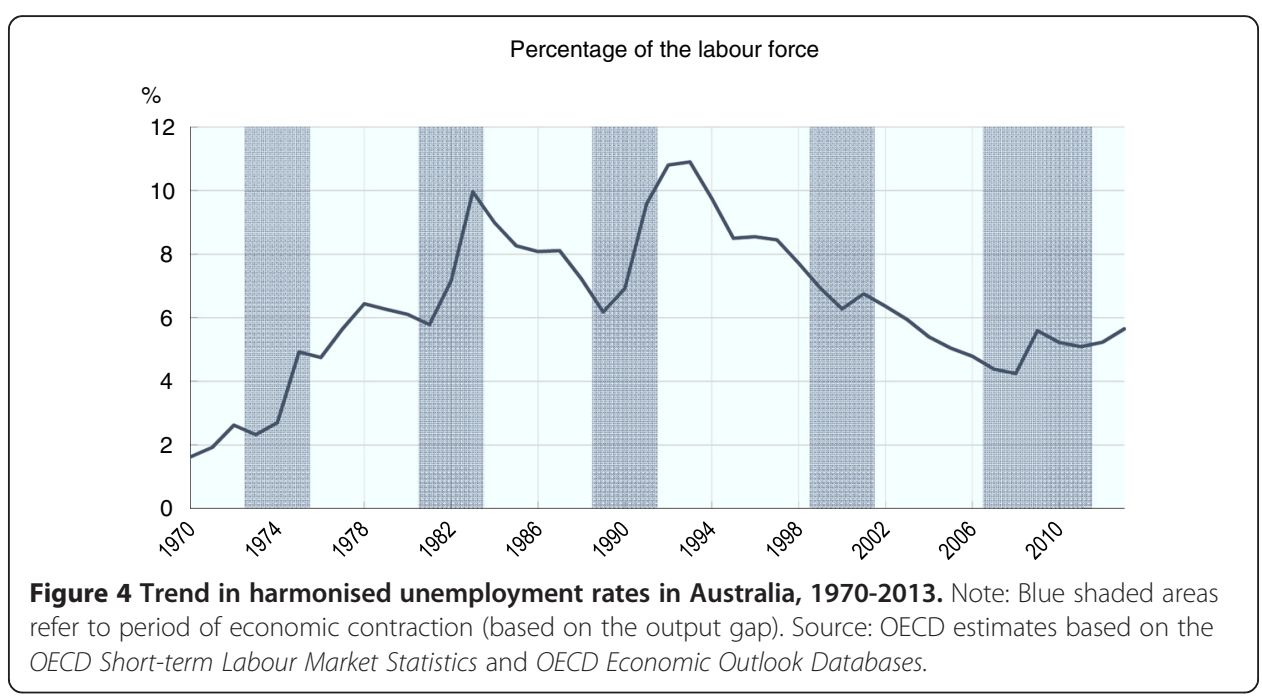


providers, has contributed significantly to this very good labour market performance over the past two decades.

Australia is a rather unique country in the OECD in terms of activation policies because it abolished the public employment service in the mid-nineties, and now there are only private providers of employment services competing under contracts from the national ministry. Some other OECD countries have ventured part of the way down this route: the Netherlands, and the United Kingdom are two leading examples, soon to be joined by Ireland, but none has gone so far as to abolish its PES.

The private providers in Australia are a mix of profit and not-for-profit providers of employment services. When the first contract round was introduced in the late nineties, there were three hundred providers. Currently, there are around 90 contracted providers of employment services, so the employment services market has undergone significant consolidation over the past two decades. The providers compete with each other at over 1,600 sites throughout Australia. Some of the leading providers are not-for profit organisations, such as the Salvation Army or Mission Australia. But there are also very large private providers such as MAX Employment who are extremely active in the market as well.

The providers compete on the basis of pay-for-performance contract which are drawn up, designed and monitored by the Australian Department of Employment. The government issues contracts to the providers based on performance for periods of three to four years. Provider performance is rated under this system. There is a form of ratings which are called star ratings, which are based mainly on econometrically-adjusted estimates of the performance of the providers, taking account of the caseload and the state of the local labour market and other factors. Providers are driven out of the market at the end of the contract period if their performance is not judged to be up to standard. Or some of them go out of business because they are unable to make money from the remuneration that they get under the contract.

While there are no experimental studies of the impacts of activation in Australia, there are some very good quasi-experiments which back up the OECD (2012b) conclusion that the system of a quasi-market with contracting of this kind in Australia has worked in terms of contributing to the relatively good labour market performance of the past two decades. Naturally, other factors such as the prolonged terms-of-trade boom and the major reform of collective bargaining arrangements in Australia over the same period have also contributed to this performance, but it seems undeniable that effective activation has to take part of the credit too.

However, while it has worked very well for activating unemployment benefit recipients and more recently for activating sole parents with young children, the quasimarket system has been much less successful in terms of activating disability benefit recipients. Those are people who are on long-term sickness or disability benefits who have been judged to have very reduced work capacity. The system was extended in the recent contract round to include these recipients, but the results in terms of speeding up the exit rate from benefits to sustainable jobs are much less satisfactory for that group than they have proved to be for UI benefit recipients or recipients of sole-parent benefits. And that is the major challenge that the Australian authorities face as they go into a new contract round. How do they make the private providers more responsive and more active in terms of helping people with long-term disability and health problems to get off benefits and into work, even into some form of part-time work? 
4.5 Switzerland: controlled decentralisation of the PES and germanic discipline combine to deliver effective activation

Figure 5 shows that, while there was a steep jump in the Swiss unemployment rate in the early 1990 s from about $1 \%$ to $4 \%$, since then it has remained broadly stable around this level with some cyclical variations. It goes without saying that an unemployment rate around $4 \%$ would be regarded as a miracle outcome in other European countries: at the end of 2013, for example, the lowest unemployment rate in the EU28 was 4.9\% in Austria.

Duell et al. (2010b) argue that specific features of the Swiss activation system have contributed to this favourable outcome. Switzerland has a relatively generous UI system compared with other countries, and it has a very long and strong tradition of decentralisation of responsibilities for labour market policies to the cantons. In Switzerland, there is a very strong decentralisation of active labour market programmes under controls, combined with a certain Germanic discipline ${ }^{16}$. Switzerland has a totally decentralised network of employment offices across the 26 cantons. Once you have exhausted UI benefits, the assistance benefits are 100\% financed at the cantonal level.

The Swiss approach to activation seeks to offset the impact of relatively generous UI benefits on work incentives by strict enforcement, of job-search requirements, relatively high spending on ALMPs (in 2012, Switzerland spent $0.6 \%$ of GDP on ALMPs) and generous in-work benefits to encourage the unemployed to accept low-wage jobs. Legislation in Switzerland requires the unemployed individuals to do all they can to shorten the duration of their unemployment spells, and the success in achieving these objectives is a very important outcome measure in the national performance rating system that exists for the local employment officers. Publication of the ratings for each local PES office has helped to raise the average performance of the system nationwide.

In addition, some novel evaluation evidence that has been produced using Swiss data shows that the PES caseworkers do play an important role in determining successful outcomes in terms of increasing the exit rate from UI benefits to work ${ }^{17}$. And the kinds of strategies that the caseworkers use to nudge their clients into jobs are also very important elements in a successful outcome. The role of caseworkers and the strategies they adopt to assist their clients to find work is an under-researched topic in the

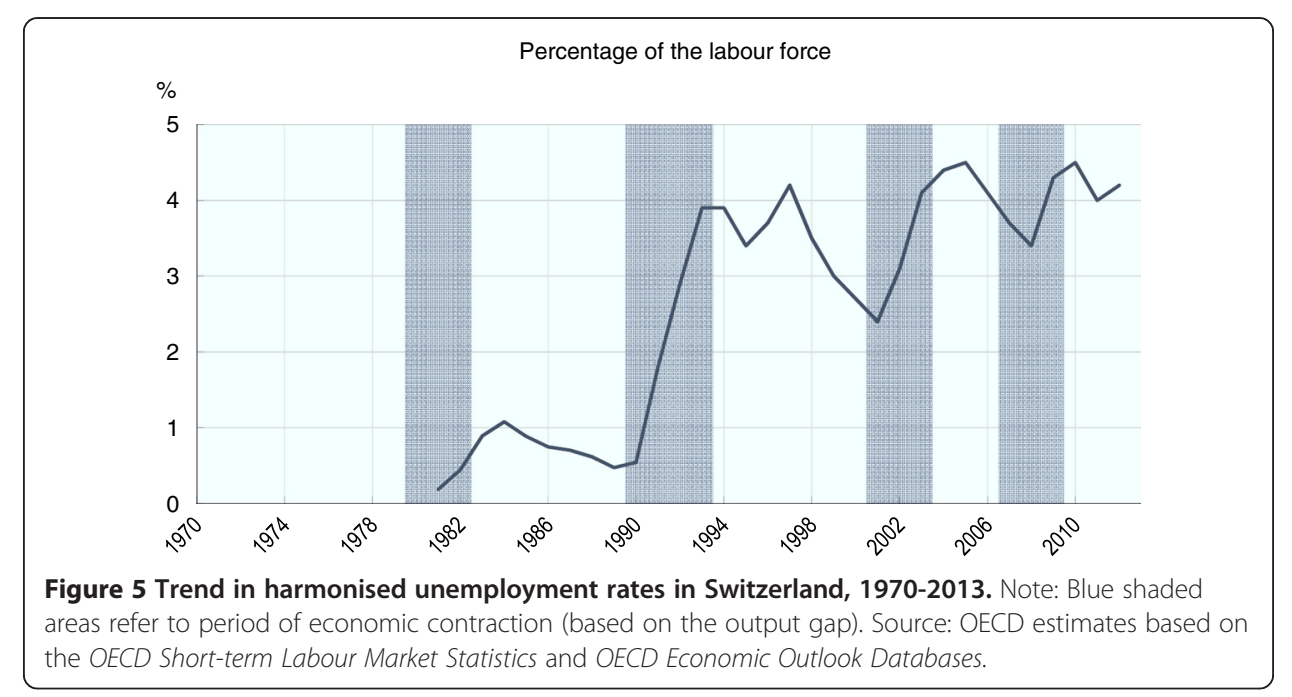


literature on what makes an activation approach work, and the Swiss case study shows that they matter.

However, the effective activation stance towards recipients of UI benefits has meant that the Swiss PES has devoted less attention to other, more difficult-to-place jobseekers. This partly explains the fact that the share of long-term unemployment in Switzerland was $33 \%$ in 2013, almost equal to the OECD average of around $35 \%$, while its unemployment rate was much below average.

At the same time, the numbers of working-age adults receiving disability benefits has risen sharply over the past two decades, with much of the growth being driven by mental ill-health. By 2012, 4.7\% of the population aged 20-64 was in receipt of a disability benefit. This has proved to be very costly for the public purse: OECD (2013c) notes that in 2008 Switzerland spent 2.6\% of GDP on sickness and disability benefits, five times what it spent on UI and related welfare benefits.

OECD (2013c) points out that it has proved hard to transfer the success achieved in activating UI benefit recipients to disability benefit recipients. Coordination between the many actors in the health system, the cantons, the private sector (which is heavily involved in sickness health insurance and in the delivery of employment and rehabilitation services) and employers has proved difficult to achieve. While the reforms which were implemented over the past decade have had some successes-new disability benefit claims began to decline from the mid-2000s on, and the stock of claimants also began to drop a few years later-it is still an uphill task for the Swiss authorities to activate many such clients back into work, especially those suffering from mental ill-health.

\subsection{Norway: effective activation keeps unemployment low but has been much less} successful for those on long-term sickness/disability benefits

Figure 6 highlights the fact that Norway has one of the lowest unemployment rates in the OECD: it currently stands at just over 3\%. While it was about half that level in the 1970s, the 1980s and early 1990s witnessed a sustained rise in unemployment which brought it to a peak of $6 \%$ in the mid-1990s. It then began to fall back towards the $3 \%$

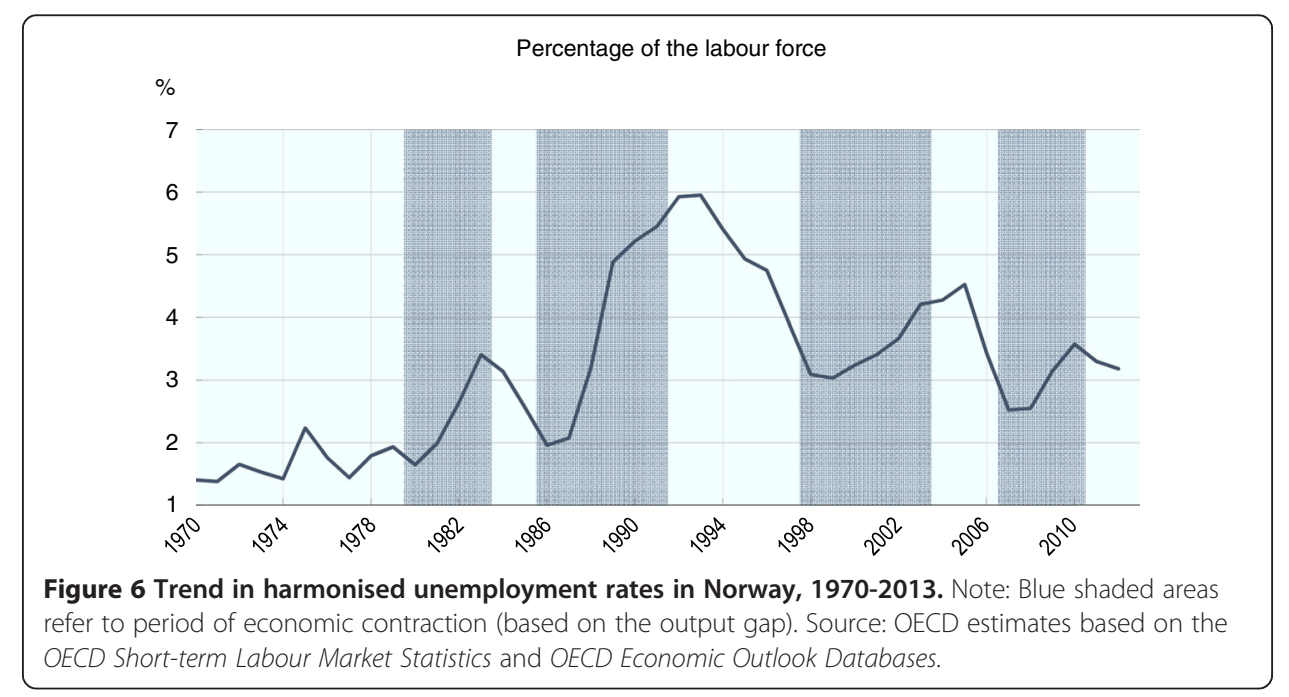


level, albeit with some cyclical variations, through the decade of the noughties up to the present day. It is noticeable that the Great Recession had a relatively mild impact on the Norwegian labour market compared with most other European or OECD countries. In addition, Norway has maintained a relatively high employment rate: in 2013, its employment rate of almost 76\% was the third highest in the OECD after Switzerland and Iceland. In addition, Norway has the lowest incidence of long-term unemployment in Europe and the second lowest in the OECD after Korea: in 2013, the share of longterm unemployment in total unemployment was only $9.2 \%$, virtually identical to its 2007 level.

However, part of the gloss of this relatively strong labour market performance is removed when one considers the other side of the coin: Norway has a relatively high benefit dependency rate among the working-age population. Duell et al. (2009b) showed that almost one fifth of the working-age population in Norway in 2007 was receiving long-term sickness or disability benefits. They also highlighted a strong trend rise in the long-term sickness/disability dependency rate over the period since 1970, a rise which continued after the mid-1990s when, as noted above, the unemployment rate dropped back from its peak towards the 3\% level. A striking stylised fact to show the magnitude of the disability benefit issue among the working-age population in Norway is that it currently spends about $5 \%$ of GDP on long-term sickness/disability benefits, whereas it only spends $0.4 \%$ of GDP on unemployment benefits! Another worrying trend is that, in recent years, more and more young people have been receiving disability benefits, often diagnosed with mental ill-health. When this is combined with evidence showing for Norway that the exit rate from long-term sickness/disability benefits to work is close to zero, this implies a huge loss of economic output, not to mention its large social cost or the cost to the public purse.

Duell et al. (2009b) argue that the Norwegian activation system has been one factor behind the relatively low unemployment rates in Norway. While the UI system is relatively generous in terms of both duration of benefits and net replacement rates, the work disincentive effects have been offset by strict eligibility criteria and relatively strict job-search requirements. Norway also spends quite a lot on ALMPs: in 2012, it spent just over $0.5 \%$ of GDP on ALMPs. In this sense, there is some similarity between the Swiss and Norwegian approaches to activation of UI benefit recipients.

The problem is that, just as in the Swiss case, the activation approach works for UI benefit recipients, but it does not work for those working-age individuals with healthrelated issues even when they have some work capacity or could be assisted to work part-time. The Norwegian government has tried two broad tracks to tackle this challenge. First, it has tried via social partnership: the unions and employers have adopted voluntary agreements at the branch and firm level (so-called Inclusive Workplace Agreements) to reduce sickness absence. But a recent OECD review notes that:

"It is hard to find hard evidence for any effects of the IWA on disability and sickness absence in the past decade ..." OECD (2013b), p.62).

It attributes this failure to the voluntary nature of the IWAs and to the fact that there has been no change to the very generous sickness benefit rate or how much of it is charged to employers ${ }^{18}$. 
The second track was the amalgamation of the PES with the benefit agency to form a new integrated agency (NAV). The NAV services were to be combined with municipal services in one-stop shops providing coordinated services to all working-age clients receiving income support.

Both tracks aim to cut sickness absence and to boost vocational rehabilitation opportunities for people with health problems so that they can re-enter the work force. But it is proving to be a very hard task in Norway to achieve these objectives. This example highlights yet again one of the limitations of existing activation strategies once the client group is expanded beyond the range of UI benefit recipients to embrace other recipients of inactive benefits who have much more heterogeneous needs and who are often at the margins of the labour force.

\subsection{United Kingdom: a successful activation regime for the unemployed but facing difficulties in extending this to other recipients of inactive benefits}

The UK unemployment rate exhibited a strong upward trend over the period from 1970 to 1986, when it peaked at over 11\% (see Figure 7). It then dropped back until the recession at the beginning of the 1990s when it rose again to just over 10\% in 1993. Subsequently, it began a sustained drop to around the $5 \%$ level before the Great Recession hit the economy. It then climbed back to 8\% in 2011 before dropping back slowly-in the third quarter of 2014, the unemployment rate was $6 \%$. The job crisis also saw an increase in long-term unemployment: its share of total unemployment rose from $23.7 \%$ in 2007 to $36.3 \%$ in 2013 . It should be added, however, that given the relatively large drop in UK output following the crisis, the rise in unemployment was much more moderate than what was predicted by most commentators when the crisis hit based on previous cyclical episodes.

But the relatively good unemployment performance of the UK economy has to be nuanced by the long-standing problem of large numbers of working-age people receiving disability benefits. OECD (2014a) notes that, at the end of 2012, over 2.5 million people (almost $7 \%$ of the working-age population) were in receipt of a disability benefit. As is the case in both Switzerland and Norway, public spending on disability

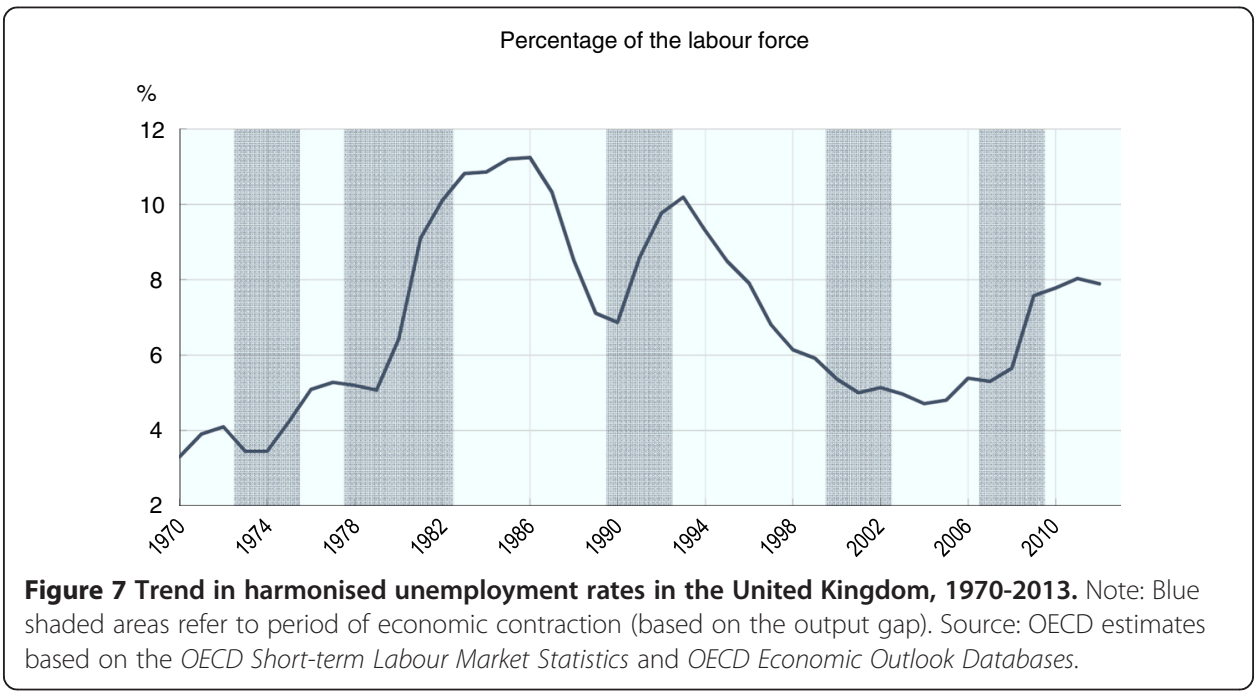


benefits in the UK far outstrips spending on unemployment benefits. It is also the case that around $40 \%$ of claimants for a disability benefit are suffering from mental ill-health.

Many commentators, including the OECD, argue that the relatively good UK unemployment record since the mid-1990s and the relatively mild hike in unemployment after 2008 owe much to effective activation policies which were first put in place in the late 1980s and subsequently much refined and extended. These policies were put in place by both Conservative and Labour governments and, most recently, by the Coalition government.

The UK activation regime began with the first Restart interviews in 1986. Benefit conditionality was tightened through the early 1990s. The unemployment benefit was replaced by the Jobseekers' Allowance (JSA) in 1996, a flat-rate benefit paid for six months. The Blair government introduced from 1998 onwards a series of so-called "New Deals" targeted at specific groups with the aim of helping them get back to work: the groups included youth, long-term JSA claimants aged 25-49, lone parents, older workers and the disabled. The PES was amalgamated with the benefits agency to form Jobcentre Plus (JCP); the new agency became fully operational in 2002.

It should be added, however, that the drop in UK unemployment from the mid-1980s until the end of the 1990s was matched by a rise in the numbers of working-age persons on Invalidity Benefit (IB). OECD (2014a) points out that the success of the activation strategy for UI benefit recipients was one of the factors driving the rise in the IB caseload in that period. This led to a shift in focus for activation measures to be extended to recipients of other inactive benefits, namely IB and sole-parent benefits. As noted above, the Pathways to Work programme was introduced in 2003 with the aim of helping IB claimants find work. However, participation in it was voluntary, at least until 2008. In 2008, IB was replaced by the Employment and Support allowance (ESA) for new claimants for disability benefits who were required to undergo both a Work Capability Assessment (WCA) and a work-focussed interview. It is noticeable that post-2008, and continuing under the Coalition government, the tightening of conditionality requirements for working-age people in receipt of disability benefits led to declines in the inflows and stocks of people on such benefits. Participation on the New Deal for Lone Parents was also on a voluntary basis in the first instance. In 2008, jobsearch conditionality was extended to lone parents whose youngest child was aged 12; in 2010 this age limit was dropped to 7.

These changes to the activation regime introduced by the Labour governments were backed up by a series of changes to the tax and benefit system and the introduction in 1999 of a national minimum wage. The aim of these changes was to "make work pay", i.e., to ensure that moving off an inactive benefit (JSA, lone-parent, IB) into work would lead to a financial gain for the individual and his family. Given the complexity of the design of the UK's benefit system-benefits are flat-rate and means-tested with a variety of top-ups via cash benefits or tax credits; there are also earnings disregards by which benefits are withdrawn as work income increases-achieving this objective is very difficult and it can create so-called "poverty traps" for certain groups. Be that as it may, these reforms did increase work incentives for many lone parents, and there is no doubt that, when combined with the activation reforms, they accounted for part of the strong rise in lone-parent employment from almost $45 \%$ in 1997 to nearly $57 \%$ in 2009 . But 
the tax credits proved very costly for the public purse and they worsened work incentives for many second earners in couple households.

When the Coalition government led by David Cameron took office in 2010, they announced significant reforms to both the activation regime and the suite of "make work pay" policies. In particular, they introduced a new flagship welfare-to-work initiative called the Work Programme. Under this initiative, private employment service providers were to be sub-contracted on a regional basis to provide reemployment services to the long-term unemployed, the young unemployed and disability benefit claimants over a two-year spell which is mandatory for claimants. The 18 prime contractors are mainly for-profit companies; though, there are also two non-profits among them ${ }^{19}$. Prime contractors are funded mainly on the basis of pay-for-sustained job outcomes; though, there is also an initial, small attachment fee ${ }^{20}$. Fees for successful outcomes are larger for more at-risk clients to reduce the well-known "creaming or parking" problem. The private providers were offered long-term (five-year) contracts to entice a sufficient number of them to enter the market.

Some elements of the design of WP were inspired by the Australian innovation, but there are also significant differences in the two models. For example, JCP continues in operation alongside the private providers to serve the needs of the short-term unemployed-unlike the Australian model where the PES was abolished. In another significant divergence from the Australian case, the Department of Work and Pensions (DWP) allows the private providers great latitude over the services they supply to their clients-the so-called "black box delivery model"-whereas its Australian counterpart lays down quite strict guidelines over the range of services to be supplied to clients. The expectation was that between 2011 and 2016, the WP would assist over three million clients.

The second Coalition flagship change to the activation regime-Universal Credit (UC)-is even more radical in ambition. It aims to unify all means-tested benefits (with the exception of the Council Tax Benefit) into a single working-age benefit with a generous earnings disregard and a single withdrawal rate of benefits against work income. Support for childcare via the benefit system will be made available for parents regardless of the number of hours they work-under the old system, they had to work at least 16 hours per week to qualify for support. The aim of UC is to improve work incentives for most families compared with the current system. It is hoped that by getting more of such families into work that this will reduce poverty and cut back on public spending on welfare benefits. UC began to be implemented slowly in 2013 and it is planned to be fully operational by 2018 .

Both flagship changes to the UK's activation regime are too recent to permit any reliable ex-post evaluations of their effectiveness. In its first year of operation, WP attracted much public criticism because job placements were below the initial projections made by DWP. But this was probably inevitable given the running-in problems associated with such an innovation in the delivery of employment services. Performance has improved since then, especially for the long-term unemployed and youth ${ }^{21}$. However, it is still the case that attempts to activate more of the disabled into work have been particularly difficult and led to much unfavourable comment in the media. Finn (2014) argues that prime contractors have been reluctant to invest in more intensive services to help the most disadvantaged clients, and the pricing model has encouraged "creaming". 
UC is also facing serious implementation issues, notably whether the information systems needed to produce real-time information on incomes will deliver effectively and on time and the Treasury will be prepared to stump up the extra funding needed to ensure that UC produces relatively few losers compared with winners. Unless the additional labour supply and work effort forthcoming from the latter outweighs the reductions in labour supply and work effort supplied by the former, it is unclear whether UC will produce a positive benefit-cost ratio.

In sum, the OECD's activation reviews have highlighted examples of both success in terms of activating UI benefit recipients (Australia, Japan, Norway, Switzerland, UK) and failures, at least until recently (Finland, Ireland). They have also highlighted the very different choices which countries have made about the design and implementation of their activation regimes, choices which have been strongly determined by different starting points, institutions and culture. Thus, countries with relatively generous benefit systems have been able to implement relatively successful activation regimes by enforcing relatively strict benefit conditionality and making effective use of ALMPs (Switzerland, Norway, Finland). Other countries have implemented successful activation regimes against a background of less generous benefit systems (Japan, United Kingdom). All but one country (Australia) has chosen to make the PES the crucial actor in delivering activation. Finally, it has proved very difficult to transfer success in activating UI benefit recipients to other recipients of inactive benefits, notably those in receipt of long-term sickness/disability benefits.

\subsection{Bottom line}

In this and the previous section, we have reviewed evidence on the effectiveness of ALMPs and activation from three different sources: (i) micro evaluations of individual ALMPs; (ii) macroeconomic evaluations of ALMPs; and (iii) country case studies of activation strategies. What are the common threads concerning outcomes which can be drawn from these sources?

First, the micro literature tells us that the composition of ALMPs matters in terms of what works and what does not, as do very practical issues of programme design and implementation. Second, the macro literature confirms that the composition of ALMPs matters for the outcomes but so does the scale of public investment in them. Both micro and macro studies suggest that ALMPs are not a magic bullet in terms of lowering unemployment. Even when they are effective, the net impacts are not large once account is taken of deadweight and displacement effects. Third, the country case studies highlight the important role that cost-effective ALMPs play in an activation strategy but show that others factors matter too if the strategy is to be successful. In particular, it is necessary to take account of the potentially important interactions between UI/UA benefit systems and the intensity of activation, especially if the former are relatively generous. In the latter case, it is vital to monitor and control tightly the job-search activity of benefit recipients in order to maintain work incentives.

\section{4. Some unanswered questions about activation}

A first, very topical question concerns the ability of activation to deliver good labour market outcomes in a steep downturn when the supply of job vacancies is reduced 
significantly. Critics of activation often claim that it is a "fair-weather" instrument: it can work only when labour demand is buoyant, making it easy to impose benefit conditionality. When labour demand is depressed, they claim it makes little sense to activate job seekers since all it will achieve is to reshuffle the queue of the unemployed.

But this negative view of activation ignores the evidence provided above that countries which have been successful in implementing activation have weathered the recent storm of the Great Recession relatively well. Countries as diverse as Finland, Japan, Switzerland and the United Kingdom have all experienced more moderate increases in unemployment since 2007-8 than would have been expected on the basis of previous cyclical patterns. This suggests that effective activation strategies can help make labour markets more resilient to adverse demand shocks.

But it is one thing to argue that effective activation can work in bad times as well as good times; it is another to argue that the mix of policies underlying an effective activation strategy does not need adjusting to the state of labour demand. For example, when labour demand is depressed, should the emphasis on benefit conditionality be weakened and more resources devoted to ALMPs ${ }^{22}$ ? This question is often posed in terms of a shift from a so-called "work-first" approach to a "train-first" approach. The rationale for such a shift in the activation mix is that the opportunity costs of investing in training for the unemployed, especially those at high risk of long-term unemployment, fall during a steep downturn as the exit rates from unemployment to a job decline. There is some limited econometric evidence from the Nordic countries that suggests it is worthwhile to shift the stance of activation policies towards greater investment in long-duration training during a steep downturn ${ }^{23}$. But it is not easy to accept this argument uncritically. Investment in training tends to be more costly for the public purse than spending on other ALMPs, and it is not easy to expand the supply of costeffective training quickly in response to a cyclical downturn ${ }^{24}$.

Nor is it always clear that a "work-first" approach is less effective in a period of high unemployment. Michaelides (2013) provides experimental evidence from a reemployment programme which was implemented by the US state of Nevada during the Great Recession. This experiment required a random sample of new UI claimants to attend a one-to-one meeting with a caseworker in the first three weeks of their UI claim as a condition of remaining eligible for benefits. The purpose of the meeting was to determine whether the claimant was in fact eligible for benefits and actively seeking work. Claimants who either failed to attend the interview or failed the eligibility test were immediately disqualified from benefits. The results showed a significant cut in the average duration of unemployment and in public spending on benefits. Importantly, the programme increased significantly the exit rate from UI receipt to employment. In another study, Martins and Pessoa e Costa (2014) evaluated a large activation programme which was introduced in Portugal in 2012 when the unemployment rate hovered around 16\%. Their results showed that, despite the depressed state of labour demand, the activation programme doubled the monthly exit rate to a job.

A second question concerns how best to extend activation approaches to benefit recipients of working age who are not as close to the labour market as the typical recipient of UI benefits. Activation, as the OECD country reviews have revealed, works best for those benefit recipients who are relatively job-ready. Activation can also be relatively successful for lone parents with young children so long as the supports provided 
can help deal with child-care issues. However, the record to date shows that activation policies are less successful in helping recipients of long-term sickness/disability benefits to find work-the Australian, Norwegian, Swiss and UK reviews testify to this relative failure. In addition, other OECD reviews have highlighted the fact that a large share of the inflows to long-term sickness/disability benefits are accounted for by people with mental illhealth-employers are extremely reluctant to engage with such people.

There is another political economy issue which comes to the fore when activation approaches are extended to recipients of disability benefits: is there general public support for such a move? The evidence shows that public opinion is usually favourable to activation policies targeted to the unemployed. However, there is much less public support for extending benefit conditionality and activation approaches to people with health problems. The disabled, in particular, have very active lobby groups in all countries, and these lobbies are very reticent about activation. The UK provides a very clear example of such reticence. Since 2008, the attempt to activate ESA recipients has been a continual source of public concern, often focalising around the use (or abuse as the lobbies tend to argue) of the WCA in order to shift people off disability benefit and on to ISA. Attempts have been made to refine the WCA to remedy deficiencies, but assessments are often challenged and overturned on appeal. Nor is this problem of lack of public support for activating people with health problems confined to the UK, such reticence also exists in other countries too, e.g., Australia, Switzerland and Norway.

Given the large numbers of working-age people on such benefits and the relatively low exit rates from such benefits to work, it has to be a very high priority to determine how activation strategies can be made more effective for people with health-related issues. What mix of rehabilitation, benefit conditionality and workplace supports could work better for such people than the current one? How can one achieve the necessary coordination between the health care sector, the PES and private employment service providers, rehabilitation and employers so as to boost the employment and career prospects for the disabled with some work capacity? How can the authorities convince the public that it is legitimate to apply activation to people with health problems?

A third question concerns the kind of career opportunities which activation can generate for benefit recipients who find work. The evidence shows that many benefit recipients are activated to take low-wage jobs which do not offer great career prospects and which may not lift them and their families permanently out of poverty. So the aim of an effective activation regime should be not only to get people off benefits and into work, but also to help them access "quality" jobs. This is much easier said than done. One track has been for the PES to offer continued support to clients even after they have exited benefits into a job, with the aim of ensuring that they can stay in the job and enjoy some career progression. Such supports may involve counselling or help with training. A few countries have tried this (including the UK), but there is relatively little evaluation evidence as to its effectiveness. Another track is to reward private providers for sustainable jobs by paying outcome fees linked directly to the durability of the job and the degree of earnings progression. But there is very little rigorous evaluation evidence on such post-employment supports, so the jury is still out on this question.

Fourth, given the trend towards subcontracting private employment service providers to operate alongside the PES, or in the extreme replacing it entirely as was done in 
Australia, there are questions as to the optimal design and monitoring of contracts in order to secure the desired outcomes for the clients at an acceptable cost to the public purse. Different countries have opted for different solutions on this front, and it is unclear yet what common lessons can be drawn. Australia, which has gone down this route the longest and adopted the most radical approach of eliminating the PES, shows that it is important to learn from each contract round and to vary the terms of the succeeding contracts in ways that will improve outcomes. In particular, the Australian example shows how important it is to develop indicators to rank the performance of the private providers. Its Star Rating system is used to drive poor performers out of the market in the next contract round or to reduce the size of their client flow while expanding the market share of above-average performers ${ }^{25}$.

Another important issue associated with creating a quasi-market in employment services concerns the design of the remuneration system for the private providers. How can one minimise "creaming" of the clients by the private providers, and how can one motivate them to achieve good placements into sustainable jobs for the most disadvantaged clients? Here, we note a significant difference in the approaches followed in Australia and the UK. In the former case, two thirds of the money is tied up in service fees and the Employment Pathway Account (a fund which is earmarked for the purchase of specific employment services for the jobseeker), while only one third is tied directly to job outcomes. In the WP, attachment fees are small and will disappear after April 2014 so that provider income will then depend solely on job outcomes and sustainability in work fees. It is unclear which of these two provider payment models is optimal and under what conditions.

The final question concerns the potential role of e-services in the market for employment services: will they prove to be a help or a hindrance for effective activation? The internet has great potential to impact the recruitment market since the cost of job search and recruiting workers online is very low compared with the traditional recruitment channels including the PES. At the same time, the PES, like most public agencies, is under pressure to cut its costs and deliver its services more effectively. One possible avenue for such cost-saving is via greater reliance on e-services to help place more of its clients into jobs. This is not just a theoretical possibility. Currently, $90 \%$ of unemployment benefit recipients in the Netherlands are being treated via e-services, and only $10 \%$ of clients-those profiled as being at the highest risk of long-term unemployment-are receiving face-to-face treatment. The Finnish PES also intends to move in a similar direction in order to cut costs and target its resources more to the mostdisadvantaged job seekers. Private employment service providers have a strong incentive to rely more heavily on e-services as a way of cutting costs and boosting their profits.

We do not know how effective such e-services are nor which clients they might work for best, if they work at all. Until recently, Kuhn (2014) highlights that there was little empirical evidence that the internet was having a significant effect on job search or recruitment outcomes. However, more recent US studies suggest that the picture is changing, and workers and firms are beginning to find ways of using the internet more effectively to make job matches. But these studies relate only to the United States, and they do not focus specifically on how the internet and social networking sites have impacted the core business of the PES. 
There is also the concern that recent rigorous evaluations from Denmark, Germany and Switzerland show that PES case workers and the approaches they use to activate their clients matter for the return to work. This suggests that personalised counselling and monitoring of job-search and employability actions are important building blocks of effective activation which require face-to-face contacts with clients and which cannot be substituted for by e-services.

\section{Concluding remarks}

The concept of activating benefit recipients into work has become an important building block in OECD and EU countries' strategies to fight high unemployment. The concept has evolved over time in the light of both theoretical understanding of the interactions between benefit systems, labour market institutions and active labour market policies and detailed reviews of different countries' experiences.

An ongoing series of OECD reviews of individual countries has highlighted the fact that activation regimes differ greatly in their scope and intensity across EU and OECD countries, reflecting their different starting points, histories, institutional settings and cultures. They all involve different combinations of job-search monitoring, benefit conditionality and referral to ALMPs.

Both the macroeconometric evidence involving cross-country data sets and the detailed OECD activation reviews reveal that effective activation regimes work in the sense of assisting the unemployed to get off benefits and into work. The mix of policies which determines whether the activation strategy is effective or not varies across countries. But the evidence also shows that some countries have played lip service to activation principles or failed to implement them effectively; in these cases, the outcomes were disappointing. There is also the fact that activation regimes have proved to be most effective for UI benefit recipients and also for recipients of sole-parent benefits when assistance is provided for child care. However, the record of activating recipients of disability benefits into work is much less successful in all countries that have tried to go down this route.

Finally, the Great Recession and its aftermath have posed new challenges to activation regimes, and there remain some unanswered questions concerning key design and implementation features associated with activation.

\section{Endnotes}

1. For example, optimal tax considerations suggest, for reasonable values of labour supply elasticities, that the optimal schedule should consist of a relatively low benefit replacement rate which declines over the duration of the benefit spell. However, it is important to take note of the fact that in reality almost all benefit systems impose some conditionality requirements, e.g., that the recipient must take active steps to find work or to improve his employability. The latter require strict monitoring of jobseeker behaviour and/or referrals to specific ALMPs. If these conditions are not met, a benefit sanction is imposed. In this way, it is possible to trade-off relatively high benefit replacement rates against maintaining reasonable work incentives, as is the case in some European countries. Such a trade-off is a key part of the well-known Danish "flexicurity" model. 
2. See OECD (2013a, p.132).

3. See Baily and Tobin (1977).

4. A similar conclusion can be drawn from the cross-country analysis of the impact of ALMPs on unemployment dynamics, i.e., the inflow (outflow) rate to (from) unemployment in OECD (OECD 2009, Chapter 1).

5. See OECD (2013a, Chapter 3) for an overview of the lessons from the ongoing activation reviews.

6. See Grubb et al. (2009).

7. See Duell et al. (2009b).

8. See Duell et al. (2009a).

9. See Duell et al. (2009b).

10. See Duell et al. (2010a).

11. See OECD (2012b).

12. See OECD (2014c).

13. The terms of the troika (composed of the IMF, European Commission and the European Central Bank) bailout for Ireland have laid much emphasis on structural reforms to the benefit and activation regimes in Ireland along the lines of those spelt out in Grubb et al. (2009).

14. See Lowe (2014).

15. For a very recent critique, see Department of Public Expenditure and Reform (2014).

16. It is, however, worth noting that evaluations in Switzerland have shown that activation works better in the German-speaking cantons than it does in either the Frenchspeaking or Italian-speaking cantons. This suggests that cultural factors and/or different social norms determine partly the outcomes of activation strategies.

17. For details, see Behncke et al. $(2008,2010)$. Nor is the evaluation evidence that caseworkers can make a real difference to outcomes confined to Switzerland: see Van den Berg et al. (2012) for similar evidence from Denmark.

18. The replacement rate for a sickness absence is $100 \%$, and Norwegian employers only pay the first 16 days of sickness benefit-which is relatively short compared with the rules in other OECD countries-and after that, the benefit is paid by the public purse.

19. The prime contractors then subcontract services and clients through a supply chain which they manage.

20. However, the attachment fee is temporary, and from April 2014, prime contractors will be paid solely on the basis of employment outcomes and the degree to which they are sustainable over time.

21. See OECD (2014c) for a detailed review and critique of the Work Programme.

22. A related issue is whether the duration of unemployment benefits should vary over the business cycle in order to better support aggregate demand. See OECD (2011), pp. 68-71) and Lalive et al. (2013) for discussions of this issue.

23. See Forslund et al. (2011) and Norlund (2009).

24. There is also the non-negligible hurdle to overcome that many countries lack adequate performance management systems to benchmark the quality of training provided to the unemployed by either public or private training providers.

25. The use of Star Ratings as a means of raising the average performance of the private providers marks a sharp contrast between the Australian and Dutch experiences 
with activation relying upon private providers. The latter devolved responsibility for the provision of most activation services to the most at-risk groups to the municipalities to subcontract with private providers. But no nationwide system to benchmark provider performance was put in place alongside this shift in delivery of the services. This is one important explanation why the Dutch experience with subcontracting private providers of employment services has been much less successful than the Australian experience.

\section{Appendix 1. A brief history of the activation concept}

There is an exhaustive discussion of how the concept has evolved from the 1950s to the present day in Weishaupt (2011). It suffices to say that for several decades thinking about the concept and policy recommendations were dominated by the so-called "Swedish view" of ALMPs, which is associated with the names of its principal architects, Gosta Rehn and Rudolf Meidner. Rehn also had a major influence on the international debates on the concept thanks to his position as Head of the OECD's Manpower Directorate from 1962 to 1973.

In the Rehn-Meidner model, ALMPs had a crucial role to play in helping to reduce structural unemployment and ensuring that counter-cyclical policy did not run into inflationary bottlenecks. Following the two oil shocks of the 1970s and the prolonged stagflation of the 1980s and early 1990s, this view of ALMPs still held sway. This can be seen clearly in the OECD's 1994 Jobs Study. One of the 10 principal recommendations of the Jobs Study was to "Expand and enhance active labour market policies". The thinking behind this specific recommendation was two-fold: (i) shift the weight of public spending on labour market policies away from unemployment benefits to more active measures which assist reemployment; and (ii) enhance the effectiveness of ALMPs. Another of the 10 recommendations related to the "Reform of unemployment and related benefit systems". The two-fold thrust behind this particular recommendation was: (i) to limit work disincentive effects; and (ii) reform tax/benefit systems so as to make work pay.

However, it is noticeable, with the benefit of hindsight, that there was little or no recognition in the Jobs Study of the need to take account of potentially important interactions between these two specific recommendations. The same criticism can be made of the early versions of the European Employment Guidelines which were first adopted by the Amsterdam Summit in 1997. They incorporated a guideline entitled "Transition from passive measures to active measures" under one of the four main pillars of the Guidelines, "Improving employability".

But a series of OECD and European Commission country reviews of the implementation of the Jobs Study recommendations and the European Employment Guidelines over the subsequent decade, together with academic research, has produced a major change in thinking on the appropriate definition of activation. A key paper in the latter was the 1997 paper by Coe and Snower, who highlighted for the first time the potential for complementarities between policies and institutions in the fight against high and persistent unemployment. This issue was then first investigated empirically in a crosscountry panel data study by Elmeskov et al. (1998). Since then, there have been many such empirical studies in a similar vein-see, for example, Bassanini and Duval (2006, 2009)-many of which have stressed the complementarity between ALMPs and unemployment insurance and related welfare benefit systems. 
Thus, by the time that the OECD came to reassess the pertinence of the original Jobs Study recommendations in the mid-2000s, it had adopted a much richer view of activation encompassing the interactions between UI/UA systems, ALMPs and benefit conditionality. This was fully articulated in OECD (2006) and taken on board in the later iterations of the European Employment Guidelines.

\section{Appendix 2. the OECD/Eurostat labour market policy (LMP) database}

OECD and Eurostat have been collecting and publishing comparable data on labour market policies for well over two decades. These data are widely used by analysts and policy makers. But it is important to understand the key concepts used to include or exclude specific measures in the data base. The first and most important criterion for inclusion is that it covers publically financed programmes. The second key criterion for inclusion in the database is that the measure must be targeted to a specific group of individuals who are at risk in the labour market.

At the same time, the database excludes many ALMPs which exist in a wide range of countries. Let me just cite three examples of important exclusions from the database. A first exclusion concerns in-work benefits. There are many prominent examples of these kinds of programme, including the Earned Income Tax Credit in the United States, Family Income Supplement in Ireland, the Working Tax Credit in the UK, the Prime pour l'emploi in France, etc. These are not included in the database when they are not conditional on the search for more work. A second exclusion covers measures that target all members of a group at statistical risk, for example, wage subsidies for all young people or for people employed in depressed regions. Lastly, measures that pay a wage subsidy for an indefinite period are also excluded. For example, sheltered work programmes, which generally exist for very long periods and pay one hundred per cent wage subsidies for handicapped workers, are excluded.

\subsection{Data comparability issues}

I would now like to turn to some of the comparability issues which arise when one wishes to use the data base to make cross-country comparisons. There are issues about the borderline, i.e., what is included and what is excluded from the database. One classic illustration of this is the treatment of public spending on apprenticeships which differs across countries. For example, France and Italy include most of their public spending on apprenticeships in the database. But in other countries, due to the targeting criteria, only a fraction of the total public support for apprentices is included, and only insofar as it is support that is targeted on individuals that are facing difficulties in the labour market.

Data for some of the non-EU countries can suffer from the exclusion of programmes that should be included. This is particularly a problem in some of the federal nonEuropean countries, e.g., the US, Canada and Australia. So the coverage of ALMPs at the sub-national level in federal countries may well be underestimated. 
Perspectives from China and the EU", Chengdu, China, 25-26 March. I am very grateful to the Commission for their financial support for the paper. I am also very grateful to Dan Finn, David Grubb, Maria Jepsen, Guenther Schmid, Juan Jimeno and a referee for their helpful comments, to Sebastien Martin and Agnes Puymoyen for statistical assistance, and to Helena Treadwell-Guedj for secretarial assistance. I alone am responsible for any errors in the paper. Responsible editor: Juan F Jimeno

Received: 19 August 2014 Accepted: 6 February 2015

Published online: 28 February 2015

\section{References}

Baily MN, Tobin J (1977) Macroeconomic effects of selective public employment and wage subsidies. Brookings Pap Econ Act 2:511-544

Baker D, Glyn A, Howell DR, Schmitt J (2005) Labor market institutions and unemployment: a critical assessment of the cross-country evidence. In: Howell DR (ed), Fighting unemployment: the limits of free market orthodoxy, Oxford University Press

Bassanini A, Duval R (2006) Employment patterns in OECD countries: reassessing the role of policies and institutions. OECD Social, Employment and Migration Working Papers 35, OECD Publishing

Bassanini A, Duval R (2009) Unemployment, institutions and reform complementarities: reassessing the aggregate evidence for OECD countries. Ox Rev Econ Pol 25:40-59

Behncke S, Frolich M, Lechner M (2008) A caseworker like me-does the similarity between unemployed and caseworker increase job placements? IZA DP 3437, Bonn

Behncke S, Lechner FM (2010) Unemployed and their caseworkers: should they be friends or foes? Jour Roy Stat Soc Series A 173:67-92

Belot M, van Ours JC (2004) Does the recent success of some OECD countries in lowering their unemployment rates lie in the clever design of their labour market reforms? Ox Econ Pap 56:621-642

Bertola G, Blau FD, Kahn LM (2002) Labor market institutions and demographic employment patterns. NBER Working Papers 9043

Blanchard O, Wolfers J (2000) The role of shocks and institutions in the rise of european unemployment: the aggregate evidence. Econ Jour 110:C1-C33

Card D, Kluve J, Weber A (2010) Active labour market policy evaluations: a meta-analysis. Econ Jour 120:F452-F477

Coe D, Snower D (1997) Policy complementarities: the case for fundamental labor market reform. IMF Staff Papers $44: 1-35$

Department of Public Expenditure and Reform (2014) Labour market synopsis, Issue 4: Active labour market programmes. Irish Government Economic and Evaluation. Service, January

De Serres A, Murtin F (2013) Do policies that reduce unemployment raise its volatility? OECD Economics Department Working Papers 1020. OECD Publishing

Duell N, Grubb D,Singh S (2009a) Activation policies in Finland. OECD Social, Employment and Migration Working Papers 98 , OECD Publishing.

Duell N, Singh S, Tergeist P (2009b) Activation policies in Norway, OECD Social, Employment and Migration Working Papers 1020, OECD Publishing

Duell N, Grubb D, Singh S, Tergeist P (2010a) Activation policies in Japan. OECD Social, Employment and Migration Working Papers 113, OECD Publishing

Duell N, Tergeist P, Bazant U, Cimper S (2010b) Activation policies in Switzerland. OECD Social, Employment and Migration Working Papers 112, OECD Publishing

Elmeskov J, Martin JP, Scarpetta S (1998) Key lessons for labour market reforms: evidence from OECD countries experience. Swed Econ Pol Rev 5:205-252

Estevao M (2003) Do active labor market policies increase employment. IMF Working Paper WP/03/234, December

Finn D (2014) The design and impact of the work programme. Univ. of Portsmouth, mimeo

Fitoussi JP, Jestaz D, Phelps E, Zoega G (2000) Roots of the recent recoveries: labor reforms or private sector forces? Brookings Pap Econ Act 31:237-311

Forslund A, Fredriksson P, Vikstrom J (2011) What active labour market policy works in a recession? IFAU Evaluation Working Paper Uppsala, January

Grubb D, Singh S, Tergeist P (2009) Activation policies in Ireland. OECD Social, Employment and Migration Working Papers 75, OECD Publishing

Heckman JJ, Lalonde RJ, Smith JA (1999) The economics and econometrics of active labor market programs. In: Ashenfelter O, Card D (eds) Handbook of labor economics. Elsevier, 3A Amsterdam and New York

Kuhn PJ (2014) The internet as a labor market matchmaker: how effective are online methods of worker recruitment and job search? IZA World of Labor, May

Lalive R, Landais C, Zweimuller J (2013) Market externalities of large unemployment insurance extension programs. IZA Discussion Paper 7650, Bonn

Lowe S. (2014) JobPath: the proposed introduction of an employment programme in the Republic of Ireland. LSE, mimeo.

Martin JP, Grubb D (2001) What works among active labour market policies: evidence from OECD countries' experiences. Swed Econ Pol Rev 8:9-60

Martins PS, Pessoa ECosta S (2014) Reemployment and substitution effects from increased activation: evidence from times of crisis. IZA Discussion Paper 8600, Bonn

Michaelides M (2013) Are reemployment services effective in periods of high unemployment? experimental evidence from the UI system. mimeo, University of Cyprus

Nickell SJ (1997) Unemployment and labor market rigidities: Europe versus North America. Jour Econ Pers 11:55-74

Nickell SJ (1998) Unemployment: questions and some answers. Econ Jour 108:802-816 
Norlund M (2009) What works best when? The role of active labour market policy programmes in different business cycles. Int Jour Soc Wel 20:43-54

OECD (2006) OECD Employment Outlook. OECD Publishing

OECD (2009) OECD Employment Outlook. OECD Publishing

OECD (2011) OECD Employment Outlook. OECD Publishing

OECD (2012a) OECD Employment Outlook. OECD Publishing

OECD (2012b) Activating jobseekers: how Australia does it. OECD Publishing

OECD (2013a) OECD Employment Outlook. OECD Publishing

OECD (2013b) Mental health and work: Norway. OECD Publishing

OECD (2013c) Mental health and work: Switzerland. OECD Publishing

OECD (2014a) Mental health and work: United Kingdom. OECD Publishing

OECD (2014b) OECD Economic Surveys: Finland 2014. OECD Publishing

OECD (2014c) Connecting people with jobs: activation policies in the United Kingdom. OECD Publishing

Scarpetta S (1996) Assessing the role of labour market policies and institutional settings on unemployment; a cross-country study. OECD Econ Stud 26:43-98

Van den Berg G, Kjaersgaard L, Rosholm M (2012) To meet or not to meet (your caseworker) - That is the question. IZA Discussion Paper 6476, Bonn

Weishaupt JT (2011) From the manpower revolution to the activation paradigm: explaining institutional continuity and change in an integrating Europe. Amsterdam University Press

Submit your manuscript to a SpringerOpen ${ }^{\circ}$ journal and benefit from:

- Convenient online submission

- Rigorous peer review

- Immediate publication on acceptance

- Open access: articles freely available online

- High visibility within the field

- Retaining the copyright to your article

Submit your next manuscript at $>$ springeropen.com 